Известия Саратовского университета. Новая серия. Серия: Социология. Политология. 2021. Т. 21, вып. 2. С. 172-174

Izvestiya of Saratov University. Sociology. Politology, 2021, vol. 21, iss. 2, pp. 172-174

Article

https://doi.org/10.18500/1818-9601-2021-21-2-172-174

\title{
Socio-cultural context of speech conflicts
}

\section{B. R. Mogilevich}

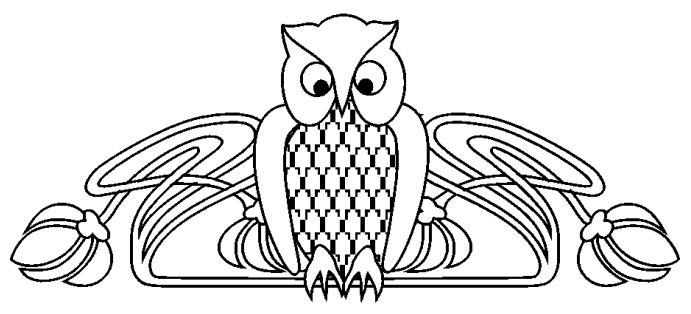

Saratov State University, 83 Astrakhanskaya St., Saratov 410012, Russia,

Bronislava R. Mogilevich, mogilevich@sgu.ru, https://orcid.org/0000-0002-4986-9183

Abstract. The article highlights the problem of socio-cultural nature of speech conflicts. Communicators' speech activity is conditioned both by inner and external factors of communication situation. Communicators' personal types are of great importance, as well as their communication schemes. Personal values and principles define human motivation and intention. The asymmetry of communication activity, a speech one included, causes a lot of various conflicts.

Keywords: speech actions, conflicts, inner and external factors, communication schemes, motivation, intention

For citation: Mogilevich B. R. Socio-cultural context of speech conflicts. Izvestiya of Saratov University. Sociology. Politology, 2021, vol. 21, iss. 2, pp. 172-174. https://doi.org/10.18500/1818-9601-2021-21-2-172-174

This is an open access article distributed under the terms of Creative Commons Attribution License (CC-BY 4.0)

Научная статья

УДК 316.347

https://doi.org/10.18500/1818-9601-2021-21-2-172-174

\section{Социокультурный контекст речевых конфликтов}

\section{Б. Р. Могилевич}

Саратовский национальный исследовательский государственный университет имени Н. Г. Чернышевского, Россия, 410012, г. Саратов, ул. Астраханская, д. 83

Могилевич Бронислава Рафаиловна, доктор социологических наук, профессор кафедры английского языка для гуманитарных направлений и специальностей, mogilevich@sgu.ru, https://orcid.org/0000-0002-4986-9183

Аннотация. В статье рассматривается проблема социокультурной природы речевых конфликтов. Речевые действия коммуникантов обусловлены внутренними и внешними факторами коммуникации. Личностные типы коммуникантов имеют большое значение, так же как и их коммуникативные схемы. Личностные ценности и принципы определяют человеческую мотивацию и интенциональность. Асимметрия коммуникативной деятельности, включая и речевую, служит причиной множества конфликтов.

Ключевые слова: речевые действия, конфликты, внутренние и внешние факторы, коммуникативные схемы, мотивация, интенциональность

Для цитирования: Mogilevich B. R. Socio-cultural context of speech conflicts [Могилевич Б. Р. Социокультурный контекст речевых конфликтов] // Известия Саратовского университета. Новая серия. Серия: Социология. Политология. 2021. Т. 21, вып. 2. С. 172-174. https://doi.org/10.18500/1818-9601-2021-21-2-172-174

Статья опубликована на условиях лицензии Creative Commons Attribution License (CC-BY 4.0)

All conflicts possess dialectic characteristics, that is they can be positive as well as negative. Positive conflict connotation is aimed at changing social conditions in the direction of bettering people's lives' quality. The negative connotation defines the changes of moral values as the main means of conflicts elimination. The speech conflicts present themselves as the actualization of all types of conflicts by means of language mechanisms. The global information social reality defines language/speech conflicts as the reflection of economic, political, cultural and religious contradiction of human society. By their nature, language conflicts are divided into inner and general ones. Language conflicts take place inside a language and are connected mainly with the choice of a state language variant among its other variants (dialects). For example, the dialect of London citizens was chosen as the state language of the United Kingdom, as well as the dialect of Moscow principality became the state language of Russia. According to P. Bourdeau, all state languages are called "legitimate" as they are the languages of administration, education, medical and social care and are acknowledged as such by the countries' population [1]. It is noteworthy that a language as the main mechanism of social communication provides 
for the access to knowledge, education, cross-cultural communication and diminishing socio-cultural inequality. That is why the importance of language/ speech conflicts generated by economic, political and socio-cultural inequality is of their speakers is far from being overestimated.

Conflicts phenomenon has been the object of humanities' investigation since the $19^{\text {th }}$ century, to name only a few of them - sociology, political sciences, linguistics and psychology. All types of social communication are actualized in the course of sociocultural interaction simultaneously reflecting them and correlating with them. In its turn, the content of social interaction (it's meanings) is embodied in the process of human communication.

Being the constituent component of the social interaction, speech communication is represented by various models [2]. From the point of view of the communication participants the following communication components can be revealed: 1) an addressee, a text communication situation, a language of communication (a code), an adequate codification of the text (language competence); 2) an addressant, a text, a communication situation, an adequate decodification of the text (a language competence). The participants of the communication process perform speech actions aimed at representing and describing the surrounding social reality. J. R. Searle, the founder of speech activity investigations, considered all speech actions as the aggregate of speech persons' perception processes. Therefore, any speech action is an activity performed by the communicators in the social reality. Thus, all speech actions performed by people are, in their essence, social actions [3]. The speech activity is conditioned by the following factors: mutual motivation of the communication participants, their socio-cultural asymmetry of their cultural capitals, linguistic ones in particular; the communication process adequacy; adherence to the principles of cooperation and politeness [4].

Really, considering the maxims of: quality (information veracity and argumentation); quantity (avoiding information abundance); relevance (information adequacy to socio-cultural situation); manner (presentation clarity and precision) contribute to the communication success. In its turn, these principles neglecting causes the emergence of communication failure. At that, very often this communication failures are conditioned no so much by the linguistic factors (an inadequate level of language competence) but by the asymmetry of their psychological profiles especially important in the course of information perception, its emotional evaluation and interpretation. In most cases human activity is actualized, mainly. in the course of speech interaction. The speech strategies chosen by the communicators are based on the aggregation of their socio-cultural profiles. Therefore, any speech action is characterized, on the one hand, by the socio-cultural models typical for the definite cultural type, but, on the other hand, it cannot but depend on the communicators' inner world schemes.
Actually, the communicators posses the definite set of values and their communication activity represents various social and ethnic groups. The asymmetry of values' sets causes the emergence of conflicts comprising the following stages:

- conflict generation in the form of potential contradictions and psychological tension;

- conflicts maturation as the process of a personal perception of definite information and expressing psychological tension;

- appearance of a reason as a starting point and launching mechanism aimed at open demonstration of communicator's beliefs and points of view;

- conflicts as the process of the open demonstration of contradictions and the communicators' awareness as well as the appearance of the supporting groups and observers;

- the conflict development in the form of deepening and changing conflict factors and characteristics;

- conflicts' consequences developing either in the direction of destructive processes predominance or with prevailing creative trends [5].

In the case of speech conflicts it is noteworthy to consider both the outer factors and the inner ones. The outer determinants are represented by the aggregation of the following components: ethno-cultural norms inherent to the territorial affiliation of communicators; the educational and professional attribution of communicators; their social roles performed in the course of their living activity. The inner factors are conditioned by communicants' psychological specific characteristics, particularly by their language competence and its conventionalism which make it possible to consider any language as a unified code for its speakers. These linguistic particular characteristics provide for establishing the interaction aimed at achieving mutual understanding among people. At the same time speech actualization is displayed in the speakers' individual choice of language variants indicating their individual image and their set of goals. It is of great importance to bear in mind that all speech conflicts present themselves as the actualization of pre-communication context of speech partners, which reflect their life principles, concepts, goals, points of view, gender and territorial attribution, social and educational statuses [6].

Consequently, communicators as speech persons choose speech variants preferable from their points of view to achieve their communication goals. As for a conflict situation, the choice of speech variants, their structure and content are conditioned by speech partners' asymmetry/symmetry. In particular, they can be presented by negative evaluation vocabulary, specific nominations, antonyms, personal pronouns "he", "she", "they", regarding the persons present in the course of conversion and so on. All speech actions present themselves as the aggregate of the following components: locution, elocution and perlocution. These constituent parts of speech actions can be considered in the following way: creating (pronounc- 
ing or writing down) an utterance in its semantic linguistic form - a locution aspect; purpose statement of the speech action - an elocution aspect; the speech action effects/consequences - a perlocution aspect. As for the elocution component of the speech action, it is especially important in the course of emerging, progressing and solving speech conflicts. The thing is, that elocution component is inseparably connected with the communication goal statement in the course of choosing semantic linguistic means. In this connection it is possible to distinguish specific instruments of constructing purposeful utterances, namely questions, arguments, orders. These linguistics constructions are mostly used in interrogative and incentive types of sentences. As for the incentive type, it is mostly presented by advice, requests, and orders - by any speech actions causing an addressee to act (from the side of the addressant). Thus, the addresant actualizes the change of causation in the addressee inner world. In other words incentive constructions are, by their nature, an addressants attempt or a wish to make an addressee perform/not perform any actions. Evidently any speech action presents itself as an interaction between an addressant and an addressee performing both speech and physical actions.

In their turn, such linguistic constructions as orders are of special importance as far as the speech conflicts are concerned. In the case of asymmetric speech actions of an addressant and an addressee (refusal from collaboration, breaks of promises, nonfulfillment of conditions, disregard of rules and so on) it is quite appropriate to speak about an addressee's opposition to an addressant's goal setting. The following linguistic constructions can serve as the examples - я против, это неправильно, невозможно, я отказываюсь, я не буду; to oppose, to contradict, to refuse, to object, to be against. In practice, the choice of linguistic means expressing disagreement and disobedience in the communication schemes can be considered as the combination of communication situation specific characteristics and the adequate mode of the communicator's behavior.

Communicators' schemes are presented as the models of participants' speech behavior manners. In their turn, these speech interaction manners incorporate such linguistic constructions as stimulus and reaction, a stimulus being presented by reports, questions, orders, requests, advice; whereas a reaction is presented by such linguistic constructions as agreement/disagreement, adoption/non adoption and so on. It is noteworthy, that such actions as neglection and evaluation are conditioned, to a great extent, by communicators' inner worlds and their personal life experiences. The asymmetry of evaluation precepts and intentions frequently causes conflicts. It is interesting to note that in most cases the communicators themselves are able to avoid or settle conflicts. In such situations inner factors acquire special impor- tance, particularly, communicators socio-cultural individual characteristics. In this connection, it is quite expedient to distinguish some main personal types:

- a destructive personal type presuming conflicts' generation and strengthening conflict situations aiming at personal domination and humiliation of others up to their suppression or elimination;

- conformity type presupposing inclination towards concessions, which very often leads to aggression;

- constructive personal type aiming at settling conflicts and choosing linguistic constructions far from aggression and insults [7].

Thus, the whole variety of human existence is reflected in a language as the main mechanism of constructing social reality. It is by means of speech activity that individuals and groups actualize their inner worlds' communication schemes which, in their turn, reflect their world views. Speech communication is carried out in the form of language interaction of various personal types. The values and behavioral modes define speech actions' motivation and intentions while their asymmetry causes conflicts, speech ones in particular.

\section{References}

1. Burd'e P. On Production and Reproduction of the Legitimate Language. Otechestvennye zapiski [Domestic Notes], 2005, no. 2 (23), pp. 1-27. Available at: https://strana-oz. ru/2005/2/o-proizvodstve-i-vosproizvodstve-legitimnogoyazyka (accessed 15 February 2021) (in Russian).

2. Komalova L. R. Speech Communication under the Situations of Language Conflicts. Minsk State Linguistic University Bulletin. Series 1: Philology, 2008, no. 5, pp. 117-126 (in Russian).

3. Syorl' Dzh. R. What is a Speech Act? Novoe v zarubezhnoj lingvistike. Vyp. 17: Teoriya rechevykh aktov [The New in Foreign Linguistics. Iss. 17: The Theory of Speech Acts]. Moscow, Progress Publ., 1986, pp. 151-169 (in Russian).

4. Grajs G. P. The Logics of Speech Communication. Novoe v zarubezhnoj lingvistike. Vyp. 16: Lingvisticheskaia pragmatika [The New in Foreign Linguistics. Iss. 16: Linguistic Pragmatics]. Moscow, Progress Publ., 1985, pp. 217-237 (in Russian).

5. Romanova V. M. The communicative conflict as the socially-linguistic phenomenon. Social Economic Phenomena and Processes, 2011, no. 10 (32), pp. 281-286 (in Russian).

6. Fillipova O. V. Lingvo-pragmatic approach to conflict interaction. Territoriya novykh vozmozhnostei. Vestnik Vladivostokskogo gosudarstvennogo universiteta ekonomiki i servisa [The Territory of New Opportunities. The Herald of Vladivostok State University of Economics and Service], 2013, iss. 1 (19), pp. 37-46 (in Russian).

7. Tretyakova V. S. The Confict as the Language and Speech Phenomenon. Izvestiya Ural skogo gosudarstvennogo universiteta [Izvestia Ural Federal University Journal], 2003, no. 27, pp. 143-152 (in Russian). 